\title{
Potato Growers on the Basis of Work Profile involved in Potato Cultivation Activities
}

\author{
Katayani $^{1}$, Dr. Rekha Dayal ${ }^{2}$, Shalini Gupta ${ }^{3}$ \\ ${ }^{1}$ Ph.D Scholar, Department of FRM, MAB College of Home Science, C.S.A.U.A. \& T., Kanpur. \\ Professor, Department of FRM, MAB College of Home Science, C.S.A.U.A. \& T., Kanpur.
}

\begin{abstract}
Potato is one of the most important food crops grown in more than 100 countries in the world. Over one billion people consume potato worldwide and it is the staple diet of half a billion people in developing countries. Present study entitled "Potato Growers on the Basis of Work Profile Involved in Potato Cultivation Activities" The pre-coded interview schedule was constructed in order to elicit information needed to obtain the objectives of the study. Multistage purposive random sampling technique was followed to select the state, district, blocks and finally respondents. District Kannauj is purposively selected as this is one of the largest potato producer districts while two blocks namely Kannauj and Jalabad were randomly selected. Two villages from each selected block i.e. Basirapur and Mahmoadpur paith from Kannauj and, Badlepurwa and Kheda from Jalalabad, selected randomly. Forty farmers from each selected village, Total sample size 160 respondents were randomly selected for final data collection. About nineteen per cent respondents were having tractors followed by 14.37 per cent respondents having electric tube well. Majority (66.25\%) respondents carried their produce to the market by bullock-carts. Little less than forty per cent respondents were dependent on river water for irrigation. Majority (48.75\%) of respondents were getting cash wage on daily basis. About 29.38 per cent respondents were engaged in potato cultivation from 10-20 years. While maximum (40.63\%) respondents were following maize-potato-tomato crop rotation.
\end{abstract}

Keywords: Potato Growers, Work Profile, Work Experience, Potato Cultivation Activities

\section{Introduction}

Potato is one of the four major food crops of the world. The other three crops being rice, wheat and maize.The global area under potato during 1998 was about 18 million ha with a total production of about 295 million tonnes. U.P. is the major potato growing state in India followed by West Bengal and Bihar with the production of 10455.30, 7482.30 and 1720.20 thousand tones, respectively. The highest productivity of the crop is in West Bengal followed by Gujrat. In respect to Uttar Pradesh, Kannauj district is the highest producer of potato followed by Farrukhabad and Agra with the production of 942299,832744 and 647025 metric tonnes and area being 34595,29793and 18156 hectares, respectively. But in average productivity (q./ha) district Agra having 1place (356.37) followed by Mathura (339.37 q/ha) and Rampur (336.49 q/ha). (U.P ke pramukh krishi ankare. Directorate of Agriculture, Lucknow, 20012002). With this point of view the study was concluded in the objective of to study the work profile of potato growers.

\section{Research Methodology}

The study was conducted in Kannauj district of Uttar Pradesh during the year 2015. The pre-coded interview schedule was constructed in order to elicit information needed to obtain the objectives of the study. Multistage purposive random sampling technique was followed to select the state, district, blocks and finally respondents. District Kannauj is purposively selected as this is one of the largest potato producer districts while two blocks namely Kannauj and Jalabad were randomly selected. Two villages from each selected block i.e. Basirapur and Mahmoadpur paith from Kannauj and, Badlepurwa and Kheda from Jalalabad, selected randomly. Forty farmers from each selected village, Total sample size 160 respondents were randomly selected for final data collection.

\section{Result and Discussion}

Table 1.1: Distributions of Respondents on the Basis of Farm implements possessed.

\begin{tabular}{|c|l|c|c|}
\hline S.No. & Farm implements possessed & Frequency & Percentage \\
\hline 1 & Tractor & 30.00 & 18.75 \\
\hline 2 & Electric tube well & 23.00 & 14.37 \\
\hline 3 & Cultivator & 12.00 & 07.50 \\
\hline 4 & Disc plough & 10.00 & 06.25 \\
\hline 5 & Thresher & 08.00 & 05.00 \\
\hline 6 & Seed drill & 17.00 & 10.62 \\
\hline 7 & M.B.plough & 05.00 & 03.12 \\
\hline 8 & Sprayer & 12.00 & 07.50 \\
\hline 9 & Duster & 06.00 & 03.75 \\
\hline 10 & Local plough & 10.00 & 06.25 \\
\hline 11 & Potato planter & 13.00 & 08.12 \\
\hline 12 & Ridge maker & 10.00 & 06.25 \\
\hline
\end{tabular}

About nineteen per cent respondents were having tractors followed by 14.37 per cent respondents having electric tube well. More than ten per cent respondents were having seed drill, whereas 8.12 per cent respondents were having potato planter. An equal percentage i.e. 6.25 per cent respondents were having disc plough, local plough and ridge maker respectively. Minimum (3.75\%) respondents were having duster while five per cent were having thresher also. An equal percentage i.e. 7.50 per cent respondents were possessing cultivator and sprayer. The data indicated that less than fifteen per cent respondents were holding farm implements and using for farm activities in their field 


\section{International Journal of Science and Research (IJSR) \\ ISSN (Online): 2319-7064}

Index Copernicus Value (2015): 78.96 | Impact Factor (2015): 6.391

Table 1.2: Distributions of Respondents on the Basis of Transport to carry the produce (Potato) to market

\begin{tabular}{|c|c|c|c|}
\hline S.No & $\begin{array}{c}\text { Means of Transport to carry } \\
\text { the produce (potato) to market }\end{array}$ & Frequency & Percentage \\
\hline 1 & Bullock cart & 106.00 & 66.25 \\
\hline 2 & Scooter/motor cycle & 12.00 & 07.50 \\
\hline 3 & Jeep & 05.00 & 03.12 \\
\hline 4 & Tractor & 10.00 & 06.25 \\
\hline 5 & Cycle & 30.00 & 18.75 \\
\hline 6 & Truck & 15.00 & 09.35 \\
\hline 7 & Mini loader /Tempo & 10.00 & 06.25 \\
\hline
\end{tabular}

Majority (66.25\%) respondents carried their produce to the market by bullock-carts while about nineteen per cent respondents used to carry the produce to the market by the means of cycle. An equal percentage i.e. 6.25 per cent respondents were using tractors or other means of transportation like mini loader or tempo etc to carry produce to the market respectively. A little less than ten per cent respondents were found using truck to carry the produce to the market. Very few i.e. only about three per cent respondents under study were carried their produce (potato) by the means of jeep, whereas 07.50 per cent respondents were using scooter/motorcycle to carry produce by to the market.

Table 1.3: Distributions of Respondents on the Basis of Sources of irrigation

\begin{tabular}{|c|l|c|c|}
\hline S.No. & Sources of Irrigation & Frequency & Percentage \\
\hline 1 & Tube well & 57.00 & 37.62 \\
\hline 2 & Pumping set & 23.00 & 14.37 \\
\hline 3 & Canal & 13.00 & 08.12 \\
\hline 4 & River & 63.00 & 39.37 \\
\hline & Total & 160.00 & 100.00 \\
\hline
\end{tabular}

Enquiry of sources of irrigation revealed that a little less than forty per cent respondents were dependent on river water for irrigation followed by 37.62 per cent respondents were using tube well. About fourteen per cent respondents under study were irrigating through the means of pumping set, whereas 8.12 per cent respondents were using canal to irrigate the crop.

Table 1.4: Distributions of Respondents on the Basis of Duration of wage payment

\begin{tabular}{|c|l|c|c|}
\hline S.No & Duration of wage payment & Frequency & Percentage \\
\hline 1 & Daily & 78.00 & 48.75 \\
\hline 2 & Weekly & 48.00 & 30.00 \\
\hline 3 & Fortnightly & 16.00 & 10.00 \\
\hline 4 & Monthly & 18.00 & 11.25 \\
\hline & Total & 160.00 & 100.00 \\
\hline
\end{tabular}

A wage is monetary compensation or remunerations paid by employer to an employee in exchange for work done. Payment may be calculated as a fixed amount for each task completed or at hourly or daily rate. Majority (48.75\%) of respondents were getting wage on daily basis followed by 30.00 per cent respondents were getting wages on weekly basis. About eleven and ten per cent respondents were paid monthly and fortnightly basis respectively.
Table 1.5: Distributions of Respondents on the Basis of Work Experience

\begin{tabular}{|c|l|c|c|}
\hline S.No & Work Experience & Frequency & Percentage \\
\hline 1 & Less than 10 & 46.00 & 28.75 \\
\hline 2 & $10-20$ & 47.00 & 29.38 \\
\hline 3 & $20-30$ & 27.00 & 16.87 \\
\hline 4 & Above 30 & 40.00 & 25.00 \\
\hline & Total & 160.00 & 100.00 \\
\hline
\end{tabular}

About 29.38 per cent respondents were engaged from 10-20 years, whereas 28.75 per cent respondents had work experience less than 10 years followed by 25.00 per cent respondents were involved about more than 30 years in potato cultivation activities. About seventeen per cent respondents under study were engaged from 20-30 years in potato cultivation activities.

Table 1.6: Distributions of Respondents on the Basis of Mode of Wage payment

\begin{tabular}{|c|l|c|c|}
\hline S.No & Mode of Wage payment & Frequency & Percentage \\
\hline 1 & Kind & 46.00 & 28.75 \\
\hline 2 & Cash & 74.00 & 46.25 \\
\hline 3 & Cash+ Kind & 40.00 & 25.00 \\
\hline & Total & 160.00 & 100.00 \\
\hline
\end{tabular}

Different methods of payment adopted by employer to employee against the services provided were enquired under mode of wage payment. Majority of respondents were getting wages as cash followed by 28.75 per cent respondents were getting wages as kind like grains, vegetables or other service as an exchange. Twenty five per cent respondents were getting wages in the form of cash and kind both.

Table 1.7: Distributions of Respondents on the Basis of Crop rotation

\begin{tabular}{|c|l|c|c|}
\hline S.No & Crop rotation & Frequency & Percentage \\
\hline 1 & Maize-potato-tomato & 65.00 & 40.63 \\
\hline 2 & Paddy-potato-summer maize & 15.00 & 9.37 \\
\hline 3 & Maize-potato-sunflower & 54.00 & 33.75 \\
\hline 4 & Maize-potato-onion & 26.00 & 16.25 \\
\hline & Total & 160.00 & 100.00 \\
\hline
\end{tabular}

Majority (40.63\%) respondents were following maizepotato-tomato crop rotation followed by 33.75 per cent respondents were following maize- potato- sunflower. About sixteen per cent respondents under study were found following maize- potato -onion crop rotation. Only 9.37 per cent respondents were following paddy-potato- summer maize crop rotation.

\section{Conclusion}

Concluding Tables that about nineteen per cent respondents were having Tractor while fourteen per cent respondents were having electric tube well. Majority of the respondents used to carry their produce (potato) to the market by bullock- cart and were using river water for irrigating the crop. Majority of the farmers were getting wages on daily basis and also involved in potato cultivation for 10 to 20 years. 46 per cent farmers used to get wages on cash basis and following maize- potato-tomato crop rotation in their fields. 


\section{References}

[1] Agricultural Statistics at a Glance, Registrar General of India.

(2004)

http://agricoop.nic.in/statatglance2004/atglance.pdf.

Retrieved on 3rd September 2011 at 11.30 am

[2] Peer, Q.J.A.; Dar, M.A.; Malik, H.A. and Kaur, J. (2014) Multiple regression analysis for adoption studies of potato growers in Jammu division. Journal of Applied and Natural Science. 6(2): 664-671.

[3] Prakash, V. (2007) Impact of socio-economic profile on potato growers. Internat. J. Plant Sci. 2(1): 247-250.

[4] Rana, R.K.; Sharma, N.; Arya, S.; Kadian, M.S.; Singh, B.P. and Pandey, S.K. (2014) Status of potato husbandry and farmer's socio-economic profile in moisture and heat prone karnataka, india.Pak. J. Agri. Sci.51 (1): 7-16.

[5] Zafar, A.; Mukul, A.; Rayhan, S.J. and Hassan, M.M. (2013) Farmer's profitability of potato cultivation at Rangpur district: the socio-economic context of Bangladesh. 